\title{
A challenging diagnosis on dermoscopy: Lichen Planus Pigmentosus
}

\author{
Dermoskopide zorlayıc bir tanı: Liken planus pigmentozus
}

\section{๑ Özlem Özbağçıvan, ๑ Banu Lebe*}

Dokuz Eylül University Faculty of Medicine, Department of Dermatology; *Department of Pathology, İmir, Turkey

Keywords: Dermoscopy, Lichen planus pigmentosus, challenging

Anahtar Kelimeler: Dermoskopi, Liken planus pigmentozus, zorlayıcı

\section{Introduction}

Since its first introduction in 1920s for the evaluation of melanocytic nevi, dermoscopy gradually has become a widely used non-invasive diagnostic tool in dermatology'. With the increasing data in this field, it has recently made a name for itself as the integral part of clinical examination for various inflammatory dermatological disorders (inflammoscopy) 2 . Although dermoscopy is considered to be an extremely helpful tool for aiding the diagnosis of skin lesions; it might not always be easy in some cases.

\section{Case Report}

A 58-year-old woman presented with a 5-month history of mildly prurutic brownish spots. Upon physical examination, a few scattered brown macules and flat papules of 0.5$1 \mathrm{~cm}$ with sharp borders on the lateral sides of the trunk, chin, and behind the left ear were observed (Figure 1). Past medical history was important for gastritis for long years, and she had been taking numerous proton pomp inhibitors irregularly. She had also been diagnosed with alopecia areata one year previously, and had been treated with topical corticosteroids without success. Detailed laboratory investigations at the time of the presentation were unremarkable. The patient underwent a dermoscopic examination, and dermoscopy revealed diffuse coarse brown globules and dotted structures with overlying slight scales in all lesions, resembling melanocytic nevi at first glance (Figure 2). A biopsy was taken from the papule located on the trunk and behind the left ear for further examination. Histopathological examinations found interface dermatitis with a lymphohistiocytic infiltrate, vacuolar degeneration of the basal layer, and apoptotic keratinocytes (Figure 3). Based on overall clinical, dermoscopic, and histologic findings, we made a diagnosis of lichen planus pigmentosus (LPP).

\section{Discussion}

LPP is a rare variant of LP with an uncertain etiology and pathogenesis. It is typically presented as dark brown to gray macules in sun-exposed areas; however, it can be generalized in some cases. This form of LP is mostly seen in patients with skin types III-IV, and may be associated with other disorders such as hepatitis C virus infection, chronic liver diseases, and autoimmune diseases as well as other variants of $L \mathrm{P}^{3}$.

Dermoscopic examination allows clinician to get a more indepth examination of the skin by visualization of structures that are not readily apparent to the naked eye. Various skin disorders exhibit distinctive dermoscopic aspects, whereas

Yazıșma Adresi/Address for Correspondence: Özlem Özbağg̣ıan MD, Dokuz Eylül University Faculty of Medicine, Department of Dermatology, İmir, Turkey Tel.: +90 2324123860 E-posta: ozlem.ozbagcivan@deu.edu.tr Geliş Tarihi/Received: 19.02.2021 Kabul Tarihi/Accepted: 23.02.2021 ORCID: orcid.org/0000-0001-7190-3969

(C)Telif Hakkı 2021 Deri ve Zührevi Hastalıklar Derneği

Türkderm-Deri Hastalıkları ve Frengi Arșivi Dergisi, Galenos Yayınevi tarafından basılmıștır. 

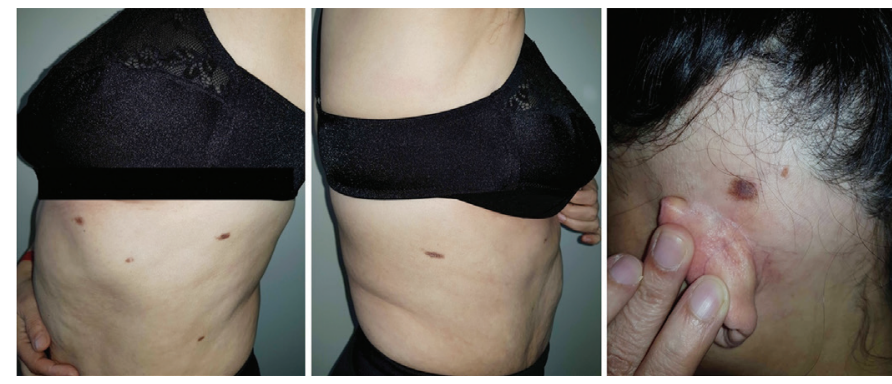

Figure 1. Scattered brown macules and flat papules of 0.5-1 cm with sharp borders on lateral sides of the trunk and behind the left ear
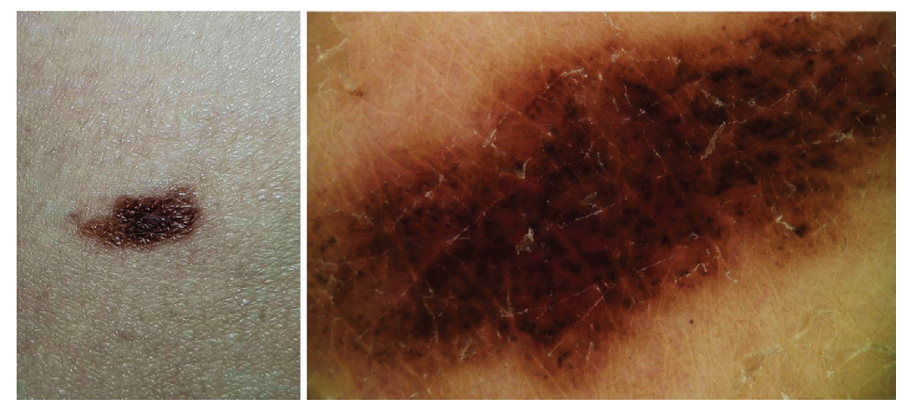

Figure 2. Diffuse coarse brown globules and dotted structures with overlying slight scales on dermoscopy, resembling a melanocytic nevi at first glance

some others do not, and might therefore be difficult to recognize. These "non-specific" findings on dermoscopy are valuable only when interpreted within the overall clinical and anamnestic context of the patient. The dermoscopic hallmark of classical LP is the Wickham striae, which may appear as shiny-whitish reticular or linear structures. Other additional dermoscopic features include peripherally located dotted or linear vessels, violet, reddish, brown, or yellow background, white-yellow dots, and some pigmented structures such as dots and globules ${ }^{4}$. Although classical LP is easily identifiable dermoscopically in many patients, it might be a challenge in some lesions especially when Wickham striae are undetectable, and/or when LP presents with pigmented forms. LPP without Wickham stria represents one of the most difficult-to-diagnose LP subtypes on dermoscopy, since it typically does not have the "classic" LP-specific criteria. Moreover, only few data are available to date in the literature on distinctive dermoscopic characteristics of LPP. Vázquez-López et al. ${ }^{5}$ defined 3 dermoscopic pigment patterns in LPP: Dots, diffuse, and mixed. Authors also suggested that these findings have also potential prognostic value because those lesions with intense granular deposits seem to be more persistent, whereas a diffuse structureless pigmentation seems to be

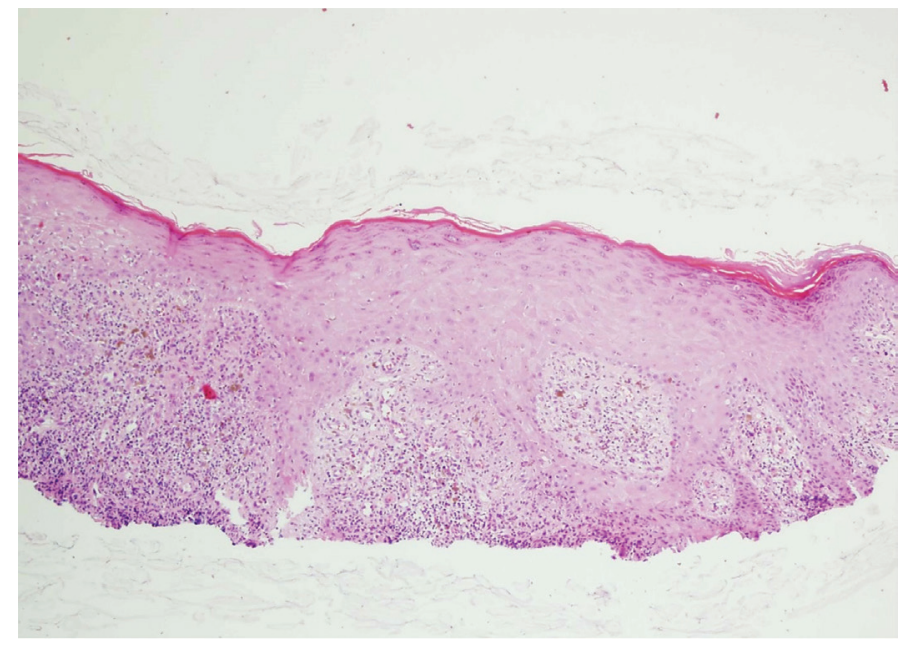

Figure 3. Interface dermatitis with a lymphohistiocytic infiltrate, vacuolar degeneration of the basal layer, and apoptotic keratinocytes (hematoxylin and eosin, $\times 10$ )

associated with earlier resolution ${ }^{5}$. The dotted pattern with coarse brown globules observed in our patient may be indicative of a poorer prognosis and a prolonged persistence of the lesions.

We have presented an example of a case in which dermoscopic differential diagnosis between LPP and other pigmented lesions was challenging. This case may help clinicians recognize these tricky to diagnose variants of LP that frequently simulate other skin lesions on dermoscopy. Although dermoscopy in nowadays is no longer a novelty nearly 100 years after its first presentation, but has become a standard practice for improving the accuracy of clinical diagnosis of skin lesions, there is still need for further research in order to increase familiarity and confidence in the field.

\section{References}

1. Domínguez-Espinosa AE: Historia de la dermatoscopia. Dermatol Rev Mex 2014;58:165-72.

2. Errichetti $E$, Stinco G: Dermoscopy in general dermatology: A practical overview. Dermatol Ther (Heidelb) 2016;6:471-507.

3. Robles-Méndez JC, Rizo-Frías P, Herz-Ruelas ME, Pandya AG, Ocampo Candiani J: Lichen planus pigmentosus and its variants: review and update. Int J Dermatol 2018;57:505-14.

4. García-García B, Munguía-Calzada P, Aubán-Pariente J, Argenziano G, Vázquez-López F: Dermoscopy of lichen planus: Vascular and Wickham striae variations in the skin of colour. Australas J Dermatol 2019;60:301-4.

5. Vázquez-López F, Maldonado-Seral C, López-Escobar M, Pérez-Oliva $\mathrm{N}$ : Dermoscopy of pigmented lichen planus lesions. Clin Exp Dermatol 2003;28:554-5. 